\title{
Ontogenetic habitat shift, population growth, and burrowing behavior of the Indo-Pacific beach star, Archaster typicus (Echinodermata; Asteroidea)
}

\author{
Arthur R. Bos • Girley S. Gumanao • \\ Marieke M. van Katwijk • Benjamin Mueller • \\ Marjho M. Saceda $\cdot$ Rosie Lynn P. Tejada
}

Received: 24 February 2010/ Accepted: 17 November 2010/Published online: 11 December 2010

(C) The Author(s) 2010. This article is published with open access at Springerlink.com

\begin{abstract}
Archaster typicus, a common sea star in IndoPacific regions, has been a target for the ornamental trade, even though little is known about its population biology. Spatial and temporal patterns of abundance and size structure of A. typicus were studied in the Davao Gulf, the Philippines $\left(125^{\circ} 42.7^{\prime} \mathrm{E}, 7^{\circ} 0.6^{\prime} \mathrm{N}\right)$, from February 2008 to December 2009. Specimens of A. typicus were associated with intertidal mangrove prop roots, seagrass meadows, sandy beaches, and shoals. Among prop roots, specimens were significantly smaller and had highest densities $\left(131\right.$ ind. $\mathrm{m}^{-2}$ ) between November and March. High
\end{abstract}

Communicated by J. P. Grassle.

Electronic supplementary material The online version of this article (doi:10.1007/s00227-010-1588-0) contains supplementary material, which is available to authorized users.

A. R. Bos $(\bowtie) \cdot$ G. S. Gumanao - B. Mueller .

M. M. Saceda - R. L. P. Tejada

Research, Extension and Production Office,

Davao del Norte State College, New Visayas,

8105 Panabo City, The Philippines

e-mail: arthurrbos@yahoo.com

\section{A. R. Bos · B. Mueller}

German Development Service-DED,

11th Floor PDCP Bank Center Building,

VA Rufino Corner LP Leviste Streets,

Salcedo Village, 1227 Makati, The Philippines

A. R. Bos

Department of Marine Zoology,

Netherlands Centre for Biodiversity Naturalis,

P.O. Box 9517, 2300 RA Leiden, The Netherlands

M. M. van Katwijk

Department of Environmental Science,

Radboud University, P.O. Box 9010,

6500 GL Nijmegen, The Netherlands organic matter in sediment and a relatively low predation rate seemed to support juvenile life among mangroves. Size and density analyses provided evidence that individuals gradually move to seagrass, sandy habitats, and shoals as they age. Specimens were significantly larger at a shoal (maximum radius $R=81 \mathrm{~mm}$ ). New recruits were found between August and November in both 2008 and 2009. Timing of recruitment and population size frequencies confirmed a seasonal reproductive cycle. Juveniles had relatively high growth rates $\left(2-7 \mathrm{~mm}\right.$ month $\left.^{-1}\right)$ and may reach an $R$ of $20-25 \mathrm{~mm}$ after 1 year. Growth rates of larger specimens $(R>30 \mathrm{~mm})$ were generally $<2 \mathrm{~mm} \mathrm{month}^{-1}$. The activity pattern of A. typicus was related to the tidal phase and not to time of day: Specimens moved over the sediment surface during low tides and were burrowed during high tides possibly avoiding predation. This is one of the first studies to document an ontogenetic habitat shift for sea stars and provides new biological information as a basis for management of harvested A. typicus populations.

\section{Introduction}

The Indo-Pacific beach star Archaster typicus is a relatively common sea star in shallow habitats from Southeast Asia to Taiwan, western Polynesia, and Australia (Colin and Arneson 1995). Probably due to its commonness, this species is, apart from the crown-of-thorns (e.g. Pratchett et al. 2009; Bos 2010; Houk and Raubani 2010), one of the more frequently studied sea stars in the Indo-Pacific. Archaster typicus is a medium-sized sea star with a radius of $15-40 \mathrm{~mm}$, but occasionally up to $70 \mathrm{~mm}$ (Schoppe 2000). Aggregations of A. typicus are often seen along shores, but may be completely invisible if specimens are burrowed under the sediment (Colin and Arneson 1995). In 
similar habitats, juvenile sea cucumbers (Echinodermata; Holothuroidea) exhibit a daily burrowing rhythm controlled by light intensity and water temperature (Mercier et al. 1999; Mercier et al. 2000). It is unknown what triggers the burrowing behavior of A. typicus, but by doing so they seem to escape predation during a certain period of the tidal phase.

Populations of Archaster typicus typically inhabit intertidal sand flats (Mukai et al. 1986), but are also found in subtidal seagrass meadows up to $1 \mathrm{~m}$ below mean low water (Bos et al. 2008a). These observations suggest that specimens of A. typicus migrate to different habitats during ontogenetic development. Ontogenetic shifts and ecological connectivity among tropical ecosystems are common and have been intensively studied for fish and decapods (e.g. Nagelkerken et al. 2008; Shibuno et al. 2008). However, only a few studies have documented changing habitat associations for sea stars. Scheibling and Metaxas (2010) found mangroves in Belize to be dominated by juveniles of the tropical sea star Oreaster reticulatus. In Panama, larger juveniles of the same species exclusively inhabited dense seagrass meadows (Guzman and Guevara 2002). In the Philippines, adults of another tropical sea star Protoreaster nodosus did not share habitats with juveniles (Bos et al. 2008b), which may yet be another indication that different life-stages may have varying habitat requirements. We hypothesized that specimens of A. typicus undergo an ontogenetic habitat shift with changing priority for mangrove, seagrass, and sandy habitats.

The reproductive strategy of Archaster typicus, uncommon among asteroids, is characterized by a matinglike behavior during which males mount on females (Boschma 1923; Komatsu 1983; Janssen et al. 1984). In sub-tropical environments in the Northern hemisphere, mating was observed between March and August (Mukai et al. 1986; Run et al. 1988). In both studies, gonad analysis confirmed that reproduction was indeed limited to that particular season. In contrast, Janssen (1991) observed mating in April and November and hypothesized that reproduction was not limited to a particular season in the tropical seas of the Philippines. The observation of mating may not necessarily be an accurate indicator of this sea star's reproductive season in tropical environments; Mating may occur throughout the year, whereas successful reproduction may be limited to a particular season. Regardless of mating, monthly monitoring of size distributions could be used to identify cohorts and provide insight into reproduction success. The presence of small juveniles throughout the year would confirm Janssen's (1991) hypothesis, whereas it would be rejected if juvenile cohorts were found only once a year.

In this study, we describe an ontogenetic habitat shift, determine the seasonality of the reproductive season, and provide age estimations by analyzing spatial and temporal patterns of abundance and size structure of the sea star Archaster typicus. Furthermore, we examine the burrowing behavior of the species in relation to time of day and tidal phase.

\section{Methods}

Quadrats

To study spatial and temporal patterns of abundance and biomass as well as size structure of Archaster typicus populations in Samal Island (Fig. 1), ten systematically positioned quadrats $(1 \times 1 \mathrm{~m})$ were sampled during every full moon (low tide at noon) between February 2008 and December 2009. Intertidal mangrove prop roots $(n=2)$, seagrass meadows $(n=4)$, and sandy beaches $(n=4)$ along the shore of Samal Island $(0-20 \mathrm{~cm}$ above mean low water [MLW]) were always sampled when they emerged at low tide. High densities and small sizes of seas stars, especially among mangrove prop roots, resulted in time-consuming collections. An increase in the number of quadrats was therefore not possible, since murky water sharply reduced the number of collected specimens during incoming tides. Sea stars were collected by carefully raking the sediment by hand to assure finding small and burrowed individuals. For comparison with the three shore habitats, the A. typicus population of a nearby sandy shoal was sampled on 20 August 2009 (Fig. 1). Low sea star density forced us to use belt transects $(50 \times 5 \mathrm{~m}, n=3)$, which were randomly positioned on the sandy sediment at low tide. All radii (ray length $R$ ) of each individual were measured from the mouth (center of the disk on the oral side) along the ambulacral groove to the tip of a ray using calipers ( $1 \mathrm{~mm}$ accuracy).

The activity pattern and burrowing behavior of Archaster typicus in relation to tide and time of day were studied during a 24-h observation in intertidal seagrass and sandy habitats in Samal Island on 15-16 September 2008 (Fig. 1). The number of visible sea stars was counted hourly in 6 fixed quadrats $(1 \times 1 \mathrm{~m})$ without disturbing the sediment. Simultaneously, sea level height was measured ( $5 \mathrm{~cm}$ accuracy), and the times of sunset and sunrise were recorded.

\section{Growth experiment}

Growth of Archaster typicus was studied in two enclosures from January 2008 to August 2009. Each enclosure $(1 \times 1 \times 0.65 \mathrm{~m})$ consisted of a PVC-pipe frame with netting material (5-mm mesh). Both enclosures were dug $0.2 \mathrm{~m}$ into the natural sandy sediment at $0.1 \mathrm{~m}$ below MLW and were additionally anchored with metal bars at each 
Fig. 1 Map of Davao Gulf with study area magnified on right. Isobaths in $300-\mathrm{m}$ intervals. Circles along shore represent mangroves. Exact location in Philippines can be found in Bos et al. (2008b)
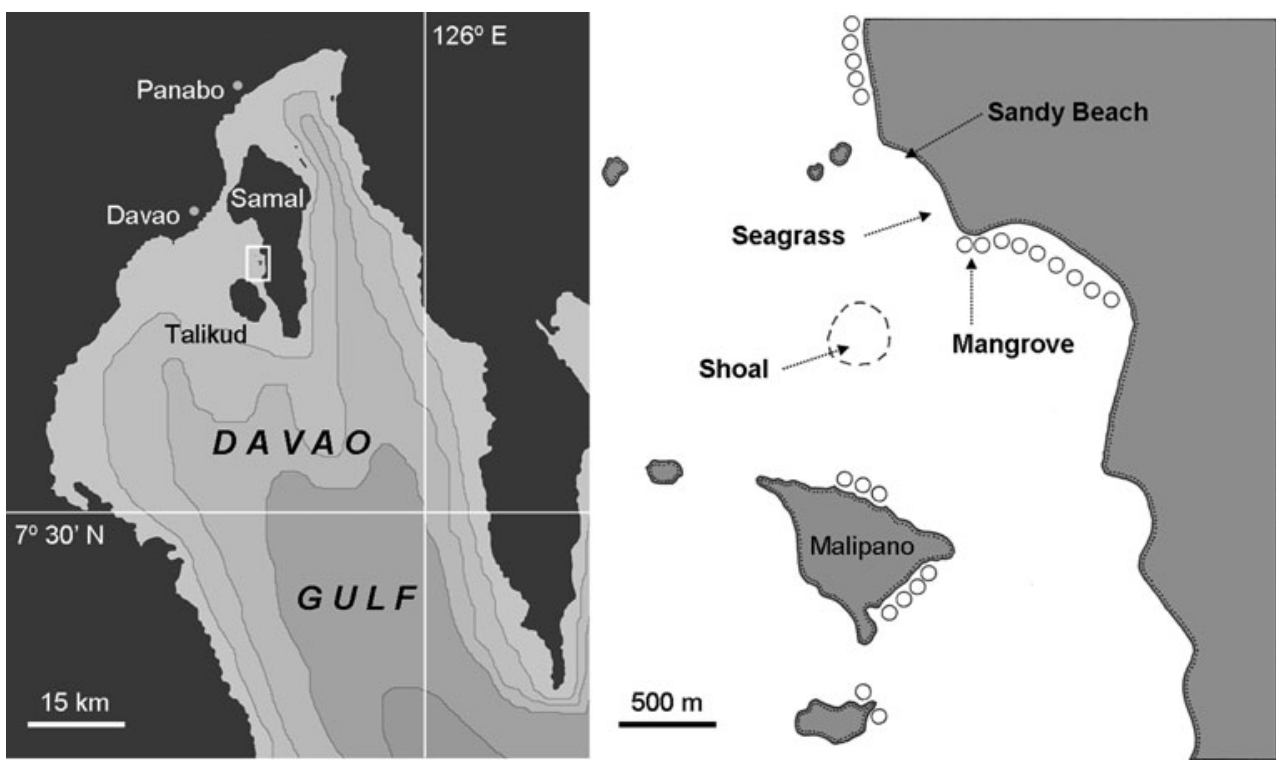

corner. A maximum of five individuals per enclosure was studied not exceeding natural densities. Growth of juveniles (mean $R<15 \mathrm{~mm}$ ) was studied in a container $(0.40 \times$ $0.25 \times 0.15 \mathrm{~m}$ ) with $50 \mathrm{~mm}$ of sediment between August 2008 and April 2009. This container was put into a 2-mm mesh bag to prevent sea star escape and placed in one of the enclosures. Small sea stars (mean $R<15 \mathrm{~mm} ; n=16$ ) were measured every two weeks and large specimens ( $n=12$ ) once every month (all rays at $1-\mathrm{mm}$ accuracy). Photographs were taken to identify individual specimens. No mortality occurred. Damaged specimens were excluded from further analysis. The growth experiment was ended in August 2009 when a storm destroyed the enclosures.

\section{Environmental parameters}

Sediment samples were collected in mangrove, seagrass, and sandy habitats on 5 September 2008 in order to explain habitat preferences of juvenile and adult sea stars. Ten cores per habitat (30 $\mathrm{mm}$ diameter, $45 \mathrm{~mm}$ deep) were collected and stored in a freezer. Seven cores of each habitat type were sieved over $2,0.5-\mathrm{mm}$, and $63-\mu \mathrm{m}$ meshes, weighed, and dried in an oven at $105^{\circ} \mathrm{C}$. The three remaining cores were weighed and dried without prior sieving to determine the fraction $<63 \mu \mathrm{m}$. The weight of the fraction $<63 \mu \mathrm{m}$ was calculated by subtracting the mean added weights of the three sieved fractions from the mean weight of the three unsieved samples. Organic matter was determined by combustion of the sediment fractions in a muffle furnace at $450^{\circ} \mathrm{C}$ for $5 \mathrm{~h}$.

Water temperature was measured with a thermometer $\left(0.2^{\circ} \mathrm{C}\right.$ accuracy) at $3 \mathrm{~m}$ below MLW during each monthly sampling between February 2008 and December 2009. Water temperature in tide pools was measured between
March and September 2009 to estimate the maximum water temperature exposure of Archaster typicus. Water temperature in the enclosures was measured in April and November 2008.

Data analysis

Mean $R$ was used to determine sea star size in the growth experiment, because intact pentamerous specimens had been selected. For the natural populations, however, maximum radius $\left(R_{\max }\right)$ was used, because a high percentage of sea stars had missing, damaged or regenerating rays. Broken rays lowered mean $R$ and affected the size-frequency distributions. For example, a specimen with four damaged rays (S1, Supplementary materials) would appear much smaller than others in the same cohort when using mean $R$. In contrast, sea star biomass was calculated with mean $R$, because broken rays reduce an individual's weight. The following radius-weight relationship was used: $W=0.0007 \times R^{2.499}$ $\left(12.0<R<80.6 \mathrm{~mm}, n=82, r^{2}=0.989\right)$.

To study growth of a natural population, model progression analysis of the size-frequencies was performed with FiSAT II using the Bhattacharya method (Gayanilo et al. 2005). Specimens were pooled among the three habitat types per sampling date. The growth rate $(G)$ was determined using the formula: $G=\left(R t_{2}-R t_{1}\right) /\left(t_{2}-t_{1}\right)$, where $R$ is radius ( $\mathrm{mm})$, and $t$ is sampling date.

Predation was the main reason for the high numbers of sea stars with fore-shortened rays in the natural population (pers. observation). Sea stars prioritize ray regeneration above somatic growth, which may cause specimens to be small in habitats where predation is high (Diaz-Guisado et al. 2006). To explain size differences among habitats, predation rate was estimated by the number of sea stars 
with damaged rays. All five radii were expressed as a percentage of $R_{\max }$ and considered damaged if $<90 \%$ of $R_{\text {max }}$. Predation differences among habitats were analyzed with contingency tables: four rows for habitat type and two columns for ray condition (complete or damaged). The null hypothesis, that predation is similar in all habitats, was tested with the Pearson $\chi^{2}$-test.

The hypotheses that sea star density, biomass, and radius did not differ among habitats were tested with the nonparametric Kruskal-Wallis test. The use of a parametric alternative was not possible, because the assumption of variance equality was not met for original and transformed data (Levene's test). Tamhane's T2 post hoc test ( $\alpha=0.05$ ), which takes unequal variances into account, was used to detect differences among individual habitats even though the habitat types defined in this study were not replicated at multiple sites. Sediment fractions of dry weight and organic matter were tested for differences among habitats with a one-way ANOVA. Post hoc analyses were done with the Tukey's honestly significant difference test $(\alpha=0.05)$.

\section{Results}

\section{Sea star activity}

The activity of Archaster typicus highly depended on the tidal cycle (Fig. 2). Generally, 12 individuals $\mathrm{m}^{-2}$ were found on the sediment surface during low tides, whereas none were observed during high tides. More specifically, the number of visible sea stars was much higher when the sea level was $<0.6 \mathrm{~m}$ than when it was $\geq 0.6 \mathrm{~m}$. These results are consistent with our observations during the extensive sampling and explain why we decided to sample on each full moon when low tide was around noon. Time of day did not affect sea star behavior (Fig. 2).

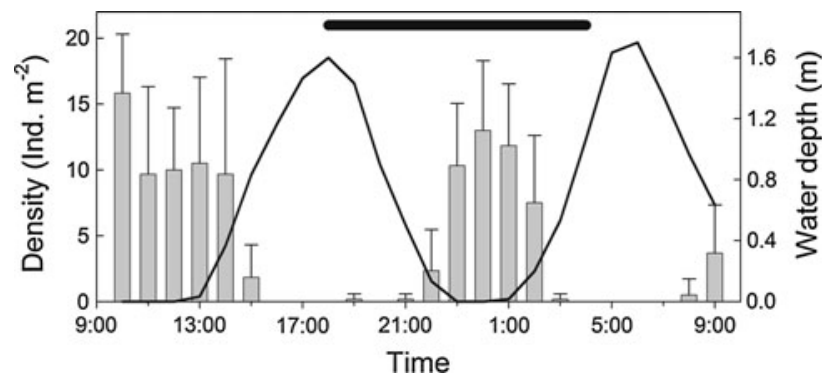

Fig. 2 Archaster typicus. Mean density (individuals $\mathrm{m}^{-2}$ ) with SD of visible sea stars in $1-\mathrm{m}^{2}$ quadrats $(n=6)$ in seagrass and sand in Samal Island observed hourly on 15-16 September 2008. Water depth (m) shows tidal amplitude (solid line). Horizontal bar indicates period from sunset to sunrise
Density, biomass, and habitat association

Sea star density was significantly different among habitats (Kruskal-Wallis, $P<0.05$ ) over 11 months (Table 1). Post hoc analysis revealed that density was generally higher in seagrass than in sand. Additionally, density in mangroves was higher than in sand in October, November, and December 2008 and in June and March 2009 (Table 1). Mean density was generally $\leq 60$ individuals $\mathrm{m}^{-2}$ in mangroves, but increased between November 2008 and March 2009 with a maximum of 131 individuals $\mathrm{m}^{-2}$ in November 2008 (Fig. 3). In seagrass, density was relatively unchanging with a mean of 40.9 individuals $\mathrm{m}^{-2}$. Mean density in sand was generally low ( $<20$ individuals $\mathrm{m}^{-2}$ ), but slightly higher between March and July 2009 with a maximum of 69.5 individuals $\mathrm{m}^{-2}$ in April 2009 (Fig. 3). In August 2009, sea star density on the shoal was 0.05 ( \pm 0.03$)$ individuals $\mathrm{m}^{-2}$. Post hoc analysis showed that this was significantly lower than in sand, but not significantly different from the August densities in mangrove and seagrass.

Sea star biomass was significantly different among habitats (Kruskal-Wallis, $P<0.05$ ) from August to November 2008 and in 4 months in 2009 (Table 1). Post hoc analysis revealed that in most cases, biomass was lower in sand than in seagrass. Biomass was relatively constant in mangroves and seagrass with a mean of 31.6 and $69.2 \mathrm{~g} \mathrm{~m}^{-2}$, respectively (Fig. 3). The high density in mangroves in November 2008 did not correspond with a high biomass, because most sea stars were small. Biomass in sand increased from $<10 \mathrm{~g} \mathrm{~m}^{-2}$ in 2008 to a peak of $125 \mathrm{~g} \mathrm{~m}^{-2}$ in April 2009 and stayed relatively high until July 2009. After July 2009, it decreased again. In August 2009 , mean biomass on the shoal was $1.14( \pm 0.74) \mathrm{g} \mathrm{m}^{-2}$. Post hoc analysis showed that this was significantly less than in seagrass, but not significantly different from the biomass in mangrove and sand.

\section{Sea star size}

Radius $R$ was significantly different among habitats between September 2008 and August 2009 and in November 2009 (Kruskal-Wallis, $P<0.05$ ). Sea stars in mangroves had a significantly lower $R$ than those in seagrass and/or sand, whereas $R$ was not significantly different between seagrass and sand (Fig. 4). In mangroves, $R$ increased from $9 \mathrm{~mm}$ in November 2008 to $20 \mathrm{~mm}$ in July 2009, while in seagrass and sand, $R$ increased from $\sim 19$ to $25 \mathrm{~mm}$. In mangroves, $R$ decreased to $9 \mathrm{~mm}$ in August, then increased during the following 2 months, and again decreased to $17 \mathrm{~mm}$ in November 2009. Both decreases coincided with the appearance of new cohorts. In August 2009, sea stars on the shoal had an $R$ of $65 \mathrm{~mm}$, 
Table 1 Archaster typicus. $P$ values resulting from Kruskall-Wallis tests comparing sea star density and biomass among three habitat types between August 2008 and December 2009. Tamhane's T2 post hoc results are coded:

$\mathrm{A}=$ Seagrass $>$ Sand;

$\mathrm{B}=$ Mangrove $>$ Sand;

$\mathrm{C}=$ Mangrove $>$ Seagrass;

$\mathrm{D}=$ Mangrove $<$ Seagrass;

$\mathrm{E}=$ Mangrove $<$ Sand

\begin{tabular}{|c|c|c|c|c|c|c|c|c|c|}
\hline & \multicolumn{5}{|l|}{2008} & \multicolumn{4}{|l|}{2009} \\
\hline & Aug & Sep & Oct & Nov & Dec & Jan & Feb & Mar & Apr \\
\hline \multicolumn{10}{|l|}{ Density } \\
\hline$P$ value & 0.011 & 1.000 & 0.023 & 0.009 & 0.011 & 0.038 & 0.027 & 0.012 & 0.034 \\
\hline Tamhane & A & - & A, B & A, B & $\mathrm{A}, \mathrm{B}, \mathrm{C}$ & A & A & $\mathrm{A}, \mathrm{B}, \mathrm{C}$ & A \\
\hline \multicolumn{10}{|l|}{ Biomass } \\
\hline$P$ value & 0.038 & 0.026 & 0.015 & 0.009 & 0.217 & 0.038 & 0.026 & 0.069 & 0.030 \\
\hline \multirow[t]{3}{*}{ Tamhane } & A & A & A, B & $\mathrm{A}, \mathrm{D}$ & - & A & E & - & $\mathrm{D}$ \\
\hline & \multicolumn{9}{|l|}{2009} \\
\hline & May & Jun & & Jul & Aug & Sep & Oct & Nov & Dec \\
\hline \multicolumn{10}{|l|}{ Density } \\
\hline$P$ value & 0.554 & 0.022 & & 0.520 & 0.020 & 0.181 & 0.032 & 0.311 & 1.000 \\
\hline Tamhane & - & $\mathrm{B}, \mathrm{C}$ & & - & A, E & - & A & - & - \\
\hline \multicolumn{10}{|l|}{ Biomass } \\
\hline$P$ value & 0.229 & 0.038 & & 0.073 & 0.057 & 0.372 & 0.148 & 0.909 & 1.000 \\
\hline Tamhane & - & A & & - & - & - & - & - & - \\
\hline
\end{tabular}

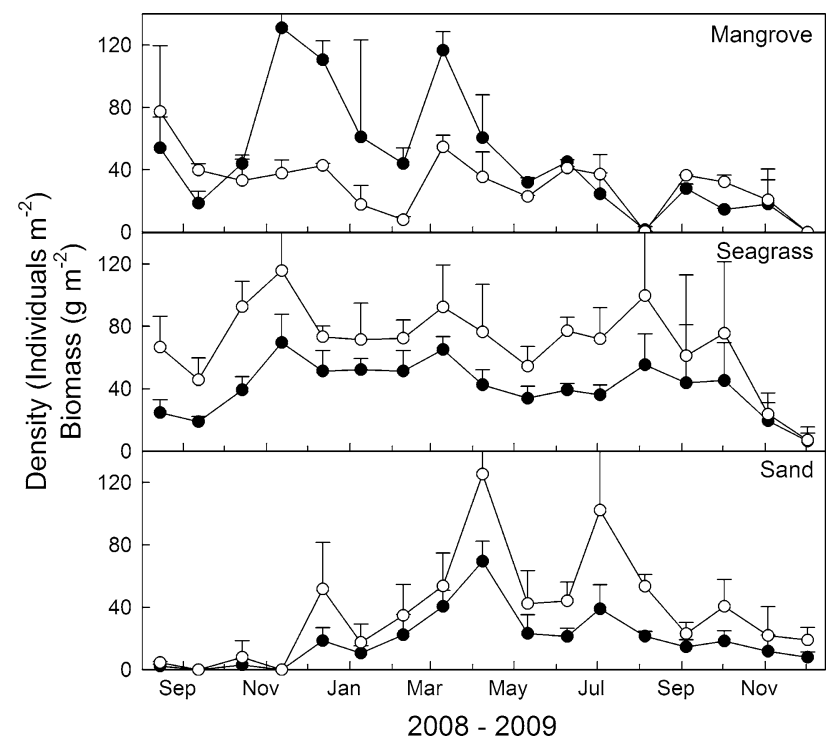

Fig. 3 Archaster typicus. Mean density (individuals $\mathrm{m}^{-2}$; filled circle) and mean biomass ( $\mathrm{g} \mathrm{m}^{-2}$; open circle) with $\mathrm{SD}$ in mangroves, seagrass, and sand between August 2008 and December 2009

which was significantly greater (Kruskal-Wallis, $P<0.01$ ) than $R$ in all shore habitats (Fig. 4). The largest specimen with an $R$ of $81 \mathrm{~mm}$ was observed on the shoal.

The number of sea stars with broken rays, an indicator of predation, was significantly different among habitats $\left(\chi^{2}, P<0.01\right)$. Sea stars with broken rays were most frequently found in seagrass and sand (40 and 39\%, respectively; Table 2). In the mangroves, $29 \%$ of the sea stars had broken rays, whereas on the shoal, this proportion was only $16 \%$ (Table 2).

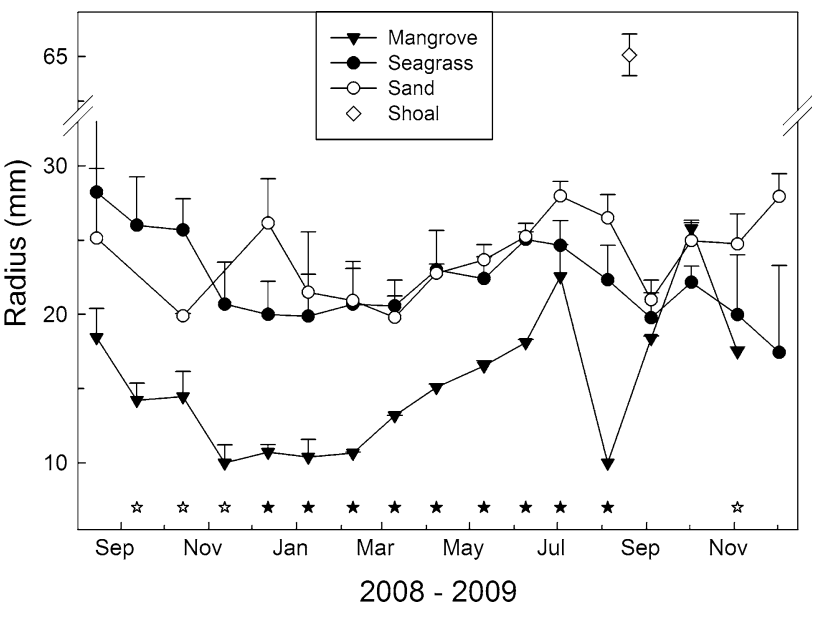

Fig. 4 Archaster typicus. Mean radius (mm) in mangrove $(n=1,673)$, seagrass $(n=3,005)$, sand $(n=1,601)$, and shoal $(n=23)$ habitats between August 2008 and December 2009. Filled and open stars indicate significant difference (Kruskal-Wallis, $P<0.05)$ between mangrove and both seagrass and sand habitats, or one of those habitats, respectively

Population size structure, growth, and age

In total, 6,180 sea stars with $R$ ranging from 2 to $46 \mathrm{~mm}$ were found in the shore habitats from February 2008 to December 2009 (Fig. 5). From February to July 2008, the majority of sea stars had an $R>10 \mathrm{~mm}$. In August 2008, a new cohort with a mode of $10 \mathrm{~mm}$ and few specimens with an $R$ of $2 \mathrm{~mm}$ were observed. In September 2008, these two cohorts had merged into a bimodal size-frequency distribution. In October and November 2008, a third cohort with mean radii of 5 and $8 \mathrm{~mm}$, respectively, in each month 
Table 2 Archaster typicus

\begin{tabular}{lrlrlll}
\hline Habitat & $N$ & \multicolumn{7}{l}{ Damaged rays } \\
\cline { 3 - 7 } & & 0 & 1 & 2 & 3 & 4 \\
\hline Mangrove & 1,642 & 71.1 & 16.2 & 7.4 & 3.9 & 1.5 \\
Seagrass & 2,952 & 59.8 & 23.1 & 10.2 & 5.1 & 1.7 \\
Sand & 1,586 & 59.1 & 22.8 & 11.2 & 4.7 & 2.1 \\
Shoal & 51 & 84.3 & 13.7 & 2.0 & 0 & 0 \\
\hline
\end{tabular}

Percentage of sea stars with zero, one, two, three, and four damaged rays in mangrove, seagrass, sand, and a shoal between February 2008 and December 2009

was added. This cohort dominated the population until July 2009 , when mean $R$ was $24.5 \mathrm{~mm}$. As in 2008, juvenile cohorts were found between August and November 2009 (Fig. 5). Modal progression analysis of the size-frequency distributions confirmed that in 2008 three and in 2009 two new cohorts were observed (Fig. 6). Growth rate of the new cohorts $(R<20 \mathrm{~mm})$ ranged from 2 to $7 \mathrm{~mm}$ month $^{-1}$, whereas growth rate of larger specimens was always $<3 \mathrm{~mm}$ month $^{-1}$ (Fig. 7). Regression analysis resulted in a significant growth function for the natural population: $\quad G=0.427+5.918 \mathrm{e}^{-0.072 R} \quad\left(n=39, \quad r^{2}=\right.$ $0.469, F=15.9, P<0.01)$. Although originating from the same population, enclosed sea stars grew much larger than those of the natural population and reached an $R$ of 40-60 mm (Fig. 6). Growth rates of enclosed specimens were similar to those of the natural population, and large enclosed specimens with $R>30 \mathrm{~mm}$ had growth rates $<3 \mathrm{~mm} \mathrm{month}^{-1}$ (Fig. 7). However, growth rates of enclosed juveniles drastically decreased between October 2008 and March 2009 (Fig. 6) and were generally
Fig. 5 Archaster typicus. Radius frequencies (pooled data for mangrove, seagrass, and sand) in Samal Island around every full moon between February 2008 and December 2009
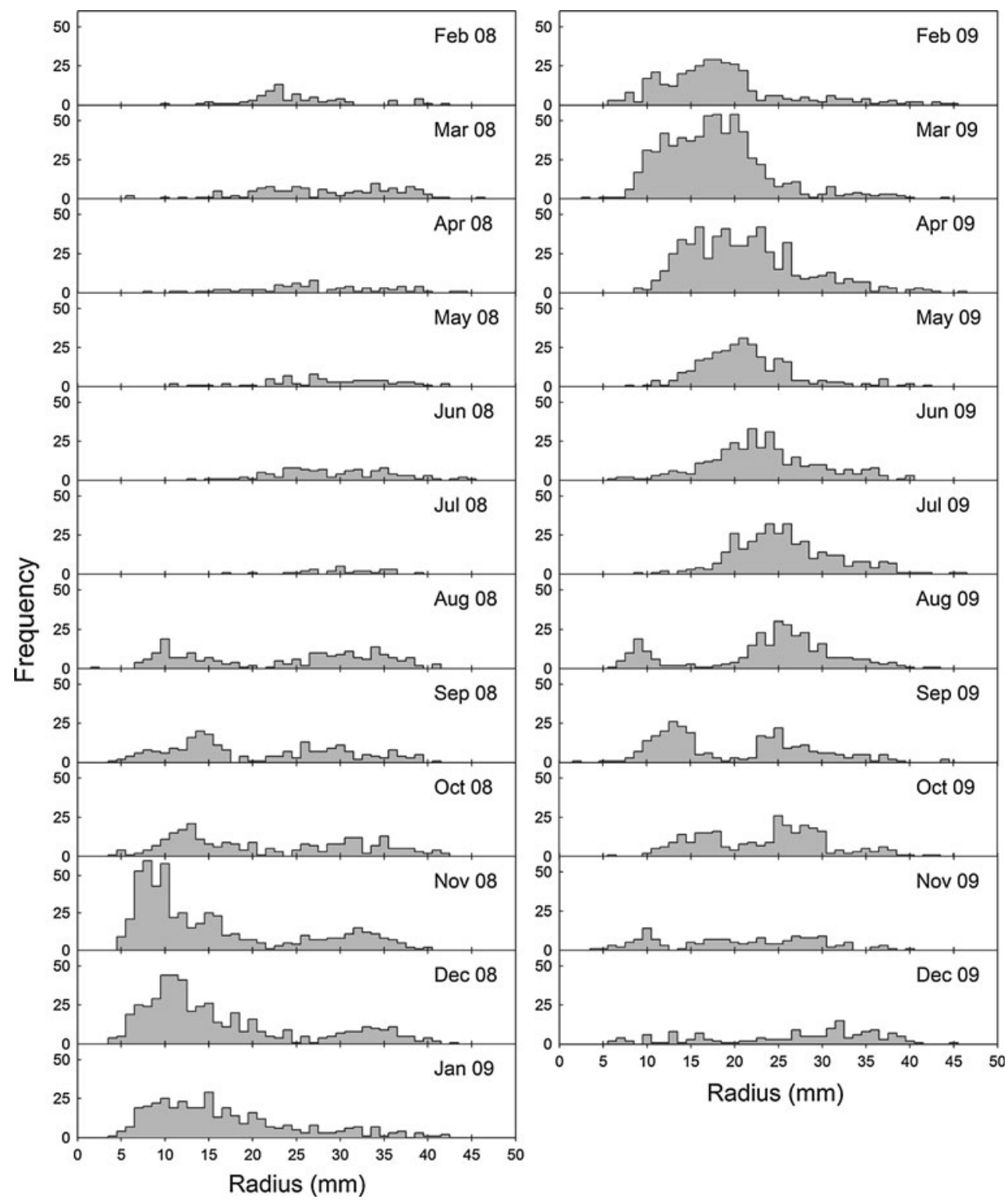


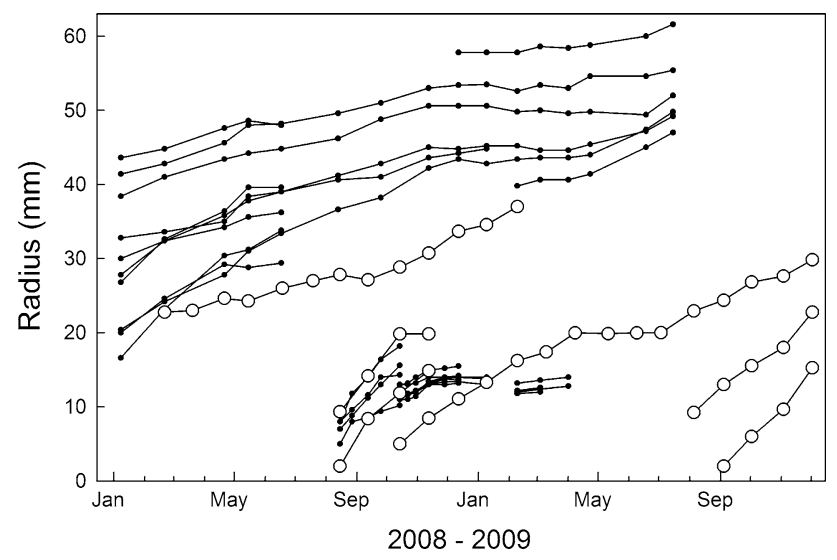

Fig. 6 Archaster typicus. Mean radius (mm) of cohorts as result of a modal progression analysis (open circle, $n=6,279$; pooled data for mangrove, seagrass, and sand) and radius increments of enclosed specimens (filled circle, $n=28$ ) between January 2008 and December 2009

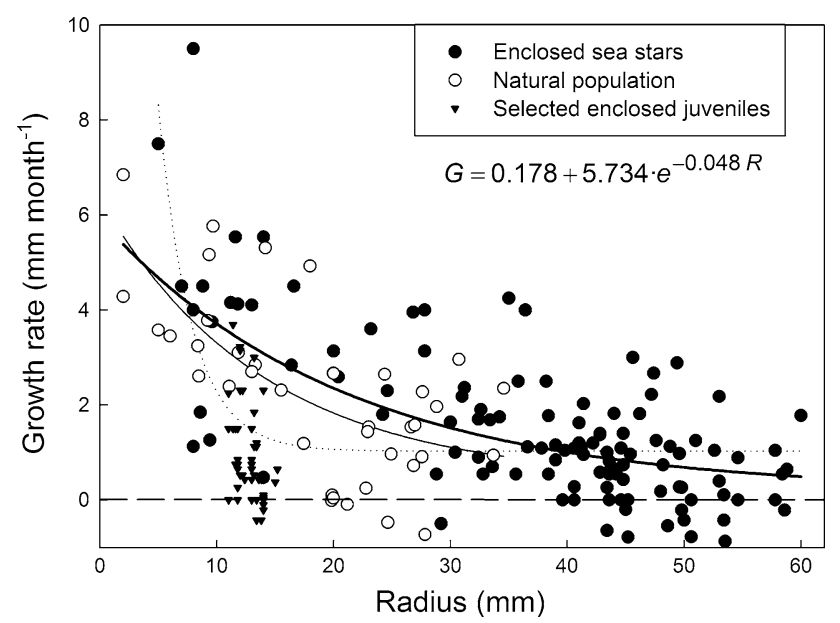

Fig. 7 Archaster typicus. Growth rates (mm month ${ }^{-1}$ ) from natural population (open circle, $n=39$; thin regression line, $r^{2}=0.469$ ) and enclosed specimens (filled circle, $n=116$, and filled inverted triangle, $n=49$; dotted regression line, $r^{2}=0.243$ ). Thick regression line represents natural population and enclosed sea stars excluding selected juveniles $\left(G=0.178+5.734 \mathrm{e}^{-0.048 R}, n=155\right.$, $\left.r^{2}=0.497\right)$

$<1 \mathrm{~mm}$ month $^{-1}$ (Fig. 7). These juveniles belonged to two batches and may have experienced disturbed growth. Regression of the growth rates of all enclosed sea stars did not result in a significant growth function, because the two juvenile batches highly affected the function (Fig. 7; dotted line). The combination of growth rates from the natural population and the enclosed specimens (excluding the juvenile batches) gave the best fit and resulted in the following growth function: $G=0.178+5.734 \mathrm{e}^{-0.048 R}$ $\left(n=155, r^{2}=0.497, F=75.2, P<0.01\right)$. After 1 year, specimens of Archaster typicus had an $R$ of $20-25 \mathrm{~mm}$ (Fig. 5). The growth function (Fig. 7) suggested that specimens with an $R$ of $60 \mathrm{~mm}$ were 3 years old.
Sediment and water temperature

The $<63-\mu \mathrm{m}$ fraction of the sandy sediment was significantly less (ANOVA, $P<0.01$ ) than in mangrove and seagrass, whereas the $63-500 \mu \mathrm{m}$ fraction was significantly less in seagrass than in the other habitat types (Table 3). The two larger sediment fractions $(0.5-2.0 \mathrm{~mm}$ and $\geq 2 \mathrm{~mm}$ ), which constituted $\sim 30 \%$ of the sediment in all habitats, were not significantly different among mangrove, seagrass, and sand (ANOVA, $P>0.05$ ). The total content of organic matter was significantly higher in mangroves (ANOVA, $P<0.05$ ) than in the other habitats (Table 3 ). Total organic matter reached $21.7 \%$ of total dry weight in mangroves, whereas this was 15.3 and $10.7 \%$ in seagrass and sand, respectively (Table 3 ). Organic matter in the $63-500 \mu \mathrm{m}$ fraction was significantly smaller in sand, whereas organic matter of the fraction $\geq 2 \mathrm{~mm}$ was significantly larger in mangroves than in the other two habitat types (Table 3 ).

From February 2008 to November 2009, mean monthly water temperature ranged between 28.0 and $34.0^{\circ} \mathrm{C}$ (Table 4). Highest water temperatures were found from May to September 2009. Water temperature in tide pools, where Archaster typicus specimens were found during low tides, reached a mean of $37^{\circ} \mathrm{C}$ and occasionally reached $40^{\circ} \mathrm{C}$ (Table 4). Mean water temperatures in the enclosures were 29.8 and $29.2^{\circ} \mathrm{C}$ in April and November 2008, respectively, and followed the seasonal trend in observations at 3-m depth.

\section{Discussion}

The sea star Archaster typicus has generally been known as an inhabitant of shallow shoreline habitats (Colin and Arneson 1995; Schoppe 2000; Bos et al. 2008a). The different life-stages of this sea star, however, inhabit a range of habitats within the shallow subtidal and intertidal zones as shown by the present study. Small juveniles were mostly found among mangrove prop roots, middle-sized sea stars in seagrass meadows, and along sandy shores, whereas large sea stars $(R<50 \mathrm{~mm})$ were exclusively found on a sandy shoal. The abundance of juveniles among mangrove prop roots, shown by the significantly smaller size in this habitat type, may be the result of higher postsettlement survival than in other habitats. The importance of mangroves as nursery habitat has been described for a range of marine and estuarine species (e.g. Nagelkerken et al. 2008), where food abundance, shelter, limited predation from fish, and reduced exposure to currents are the essential advantages for juvenile life among prop roots. However, only a few studies have mentioned this ecological role of mangroves for sea stars (Guzman and Guevara 
Table 3 Dry weight and organic material as percentage of total dry weight per sediment fraction with SD and sum of all fractions in mangrove, seagrass, and sand

\begin{tabular}{|c|c|c|c|c|c|c|}
\hline \multirow[t]{2}{*}{ Sediment fraction } & \multicolumn{3}{|c|}{ Dry weight $(\%)$} & \multicolumn{3}{|c|}{ Organic material $(\%)$} \\
\hline & Mangrove & Seagrass & Sand & Mangrove & Seagrass & Sand \\
\hline$<63 \mu \mathrm{m}$ & $11.2 \pm 3.7$ & $25.1 \pm 6.7$ & $6.5 \pm 4.3^{*}$ & $7.7 \pm 3.7$ & $5.5 \pm 0.8$ & $1.5 \pm 1.9$ \\
\hline$\geq 63 \mu \mathrm{m},<0.5 \mathrm{~mm}$ & $62.0 \pm 6.5$ & $47.4 \pm 5.8^{*}$ & $64.2 \pm 4.5$ & $3.2 \pm 0.1$ & $3.3 \pm 0.2$ & $2.3 \pm 0.3^{*}$ \\
\hline$\geq 0.5 \mathrm{~mm},<2 \mathrm{~mm}$ & $20.1 \pm 4.0$ & $19.4 \pm 5.3$ & $20.7 \pm 6.0$ & $3.0 \pm 0.1$ & $2.7 \pm 0.2$ & $3.4 \pm 1.3$ \\
\hline$\geq 2 \mathrm{~mm}$ & $6.7 \pm 2.9$ & $8.1 \pm 4.2$ & $8.6 \pm 1.9$ & $7.8 \pm 3.4^{*}$ & $3.8 \pm 0.7$ & $3.5 \pm 1.7$ \\
\hline Total & 100 & 100 & 100 & $21.7 *$ & 15.3 & 10.7 \\
\hline
\end{tabular}

* indicate significant difference with other two habitat types

Table 4 Mean monthly water temperature $\left({ }^{\circ} \mathrm{C} ; n=36\right)$ and mean water temperature in tide pools during low tides $(n=49)$ measured between February 2008 and December 2009 in the Davao Gulf

\begin{tabular}{ccccccccccccc}
\hline & Jan & Feb & Mar & Apr & May & Jun & Jul & Aug & Sep & Oct & Nov & Dec \\
\hline 2008 & - & 29.0 & 28.5 & 29.5 & 29.8 & 29.8 & - & 29.8 & 30.0 & 29.9 & 29.5 & 29.5 \\
2009 & 29.3 & 28.0 & 28.5 & 30.7 & 32.3 & 34.0 & 31.0 & 31.4 & 31.1 & - & 29.8 & - \\
Pools & - & - & 37.0 & 39.1 & 35.9 & - & 37.2 & 36.1 & 39.4 & - & - & - \\
\hline
\end{tabular}

2002; Scheibling and Metaxas 2010). Post-settlement survival of A. typicus may be high among mangrove prop roots, because this habitat provides appropriate food and protection. Indeed, we found that sediment among prop roots had significantly more organic matter. Moreover, mangrove prop roots are usually covered with a rich fouling community, which can be a food source for sea stars (Scheibling and Metaxas 2010). Also, sea stars were less frequently damaged among mangroves than in seagrass and sand. The above allows the assumption that mangroves provide an abundance of food and reduced predation pressure for A. typicus. As they grew, juveniles migrated to adjacent habitats (seagrass and sand) which resulted in a density decrease in mangroves. Although the density stayed relatively the same over time in seagrass, it simultaneously increased in sandy habitats.

Sea star radius was generally $<40 \mathrm{~mm}$ in the shore habitats, whereas specimens were significantly larger on the shoal and had a mean $R$ of $65 \mathrm{~mm}$. Growth in enclosures showed that sea stars from the shore population could actually grow larger $(40<R<60 \mathrm{~mm})$, which also suggests that specimens of a certain size leave the shore and migrate somewhere else, for example to shoals. Janssen et al. (1984) observed specimens of A. typicus $(R>50 \mathrm{~mm})$ to solely inhabit sandy patches at relatively low densities (4.1 individuals $\mathrm{m}^{-2}$ ). Similarly, we found that the density of large specimens $(R \geq 50 \mathrm{~mm})$, exclusively found on the shoal, was lower $\left(0.05\right.$ individuals $\left.\mathrm{m}^{-2}\right)$ than in all shore habitats. The relatively high densities along the shore may result in intra-specific competition for food and to avoid such competition, large specimens may migrate to offshore habitats. On the other hand, this migration could also be density dependent (and not food dependent), as was observed for the small brittle star Amphiura filiformis (Rosenberg et al. 1997). Whatever the cause, specimens of A. typicus with an $R$ of $40 \mathrm{~mm}$ are able to move at a mean speed of $\sim 0.5 \mathrm{~m} \mathrm{~min}^{-1}$ (Mueller et al. submitted), which would theoretically allow them to migrate to the shoal within $24 \mathrm{~h}$.

Although at a much larger geographical scale, two different populations of another common Indo-Pacific sea star, Protoreaster nodosus, grew to different maximum sizes. In the Davao Gulf, $P$. nodosus had an $R_{\max }$ of $140 \mathrm{~mm}$ (Bos et al. 2008b), whereas in Palau specimens reached an $R_{\max }$ of $195 \mathrm{~mm}$ (Scheibling and Metaxas 2008). Densities were similar in these populations and did not explain the size difference. One of the possible explanations, however, was a difference in predation (Bos et al. 2008c). Sea stars use most of their energy for repairing damaged body parts, which sharply reduces overall growth and as a consequence their size (Diaz-Guisado et al. 2006; Barker and Scheibling 2008). Along the shore of Samal Island, specimens of A. typicus had a higher percentage of ray damage than on the shoal, which may have been the result of greater exposure to predation. Crabs of several species, potential sea star predators (Ramsay et al. 2000), were observed along the shore, whereas they were rarely seen on the shoal (pers. observation). Also, predation by fish, especially during high tides, may play a role. An intertidal brittle star in Kenyan reef flats mainly fed during low and incoming tides and hid in crevices during high tides avoiding predation by fish (Oak and Scheibling 2006). Moreover, the burrowing behavior of A. typicus during high tides may be a strategy to avoid such predation. Although other predators 
may play a role in offshore habitats (e.g. Bos et al. 2008c; Gaymer and Himmelman 2008), predation could have had a negative impact on the growth of small specimens in the shore habitats.

Juvenile cohorts of Archaster typicus were observed between August and November, in both 2008 and 2009. From these data, we conclude that reproduction of A. typicus in the Davao Gulf is seasonal. Janssen (1991) earlier concluded that in the Philippines, A. typicus reproduces without a specific reproductive season after observing mounted sea stars in April and in November. We found single mating pairs in several months of the year, but only observed increased numbers of pairs in September and October 2008 (pers. observation). Although mating may occur throughout the year, the majority of sea stars must have synchronized their reproductive activity to produce the juvenile cohorts we observed. Modal progression analysis identified three juvenile cohorts in 2008. The first two cohorts were found before we observed mating and may have originated from a different source population. The third cohort, however, which strongly dominated the size-frequency distributions from November onward, may have been the result of mating in September and October. The expectation of observing juveniles 1 month after mating seems reasonable, because the larval period of A. typicus lasts $\sim 30$ days (McEdward and Janies 1993). In Taiwan and Japan, A. typicus reproduces between March and August (Mukai et al. 1986; Run et al. 1988), which confirms that mating may take place earlier in the year. Combining results, we conclude that reproduction of A. typicus in the Davao Gulf takes place between June and October.

Sea star growth in the natural population was relatively similar to the growth of enclosed specimens. However, in the enclosures, growth of juveniles was strongly inhibited from October 2008 to March 2009. This difference may have been the result of exposure to different water temperatures. The natural population was exposed to high water temperatures in tide pools (e.g. $37^{\circ} \mathrm{C}$ in March 2009), whereas in the enclosures, water temperature hardly fluctuated with the tide. Moreover, shading in the containers (within the enclosures) may have lowered water temperature and have negatively affected growth rates of small juveniles.

Archaster typicus is one of the target sea stars for the international ornamental trade, and some local populations in the Philippines are subject to intense harvesting (Bos et al. 2008a). To manage exploited populations, there is a need for information about habitat associations of the different life-stages and the population dynamics of the species. Our data provide a solid basis for future management, because we studied a natural population that has not been affected by collection.
Acknowledgments We thank I. Ebol, C. Ganadores, E. Glimada, S. Nitza, S.A. Nitza, D. Padrogane, C. Petiluna, F. Salac, J. Salinas, and I. Santamaria for supporting field and laboratory work. We greatly acknowledge A. Sales and D. Speckmaier from the Department of Science and Technology in Davao City, who organized the combustion of sediment samples. Also we thank the personnel of the Department of Environment and Natural Resources (Region XI) and the LGUs in Samal Island for their continued support. Two anonymous reviewers and S. Burton are acknowledged for their comments on an earlier version of this manuscript. The performed experiments complied with the current laws of the Republic of the Philippines.

Open Access This article is distributed under the terms of the Creative Commons Attribution Noncommercial License which permits any noncommercial use, distribution, and reproduction in any medium, provided the original author(s) and source are credited.

\section{References}

Barker MF, Scheibling RE (2008) Rates of fission, somatic growth and gonadal development of a fissiparous sea star, Allostichaster insignis, in New Zealand. Mar Biol 153:815-824

Bos AR (2010) Crown-of-thorns outbreak at the Tubbataha Reefs UNESCO World Heritage Site. Zool Stud 49:124

Bos AR, Gumanao GS, Alipoyo JCE, Cardona LT, Salac FN (2008a) Population structure of common Indo-Pacific sea stars in the Davao Gulf. Philipp Assoc Mar Sci Proc UPV J Nat Sci 13:11-24

Bos AR, Gumanao GS, Alipoyo JCE, Cardona LT (2008b) Population dynamics, reproduction and growth of the Indo-Pacific horned sea star, Protoreaster nodosos (Echinodermata; Asteroidea). Mar Biol 156:55-63

Bos AR, Gumanao GS, Salac FN (2008c) A newly discovered predator of the crown-of-thorns starfish. Coral Reefs 27:581

Boschma H (1923) Über einen Fall von Kopulation bei einer Asteroide (Archaster typicus). Zool Anz 58:283-285

Colin PL, Arneson C (1995) Tropical Pacific invertebrates. Coral Reef Press, California

Diaz-Guisado D, Gaymer CF, Brokordt KB, Lawrence JM (2006) Autotomy reduces feeding, energy storage and growth of the sea star Stichaster striatus. J Exp Mar Biol Ecol 338:73-80

Gayanilo FC, Sparre P, Pauly D (2005) FAO-ICLARM Stock Assessment Tools II (FiSAT II) user's guide. FAO computerized Information Series (Fisheries) No. 8

Gaymer CF, Himmelman JH (2008) A keystone predatory sea star in the intertidal zone is controlled by a higher-order predatory sea star in the subtidal zone. Mar Ecol Prog Ser 370:143-153

Guzman HM, Guevara CA (2002) Annual reproductive cycle, spatial distribution, abundance, and size structure of Oreaster reticulatus (Echinodermata: Asteroidea) in Bocas del Toro, Panama. Mar Biol 141:1077-1084

Houk P, Raubani J (2010) Acanthaster planci outbreaks in Vanuatu coincide with ocean productivity, furthering trends throughout the Pacific Ocean. J Oceanogr 66:435-438

Janssen HH (1991) Surprising findings on the sea star Archaster typicus. Philipp Sci 28:89-98

Janssen HH, Orosco C, Largo D, Ayson F, Uy W (1984) Some recent findings on the sea star, Archaster typicus Mueller and Troschel 1840. Philipp Sci 21:51-74

Komatsu M (1983) Development of the sea star, Archaster typicus, with a note on male-on female superposition. Annot Zool Jpn 56:187-195 
McEdward LR, Janies DA (1993) Life cycle evolution in asteroids: what is a larva? Biol Bull 184:255-268

Mercier A, Battaglene SC, Hamel JF (1999) Daily burrowing cycle and feeding activity of juvenile sea cucumbers Holothuria scabra in response to environmental factors. J Exp Mar Biol Ecol 239:125-156

Mercier A, Battaglene SC, Hamel JF (2000) Periodic movement, recruitment and size-related distribution of the sea cucumber Holothuria scabra in Solomon Islands. Hydrobiologia 440:81-100

Mukai H, Nishihira M, Kamisato H, Fujimoto Y (1986) Distribution and abundance of the sea star Archaster typicus in Kabira Cove, Ishigaki Island, Okinawa. Bull Mar Sci 38:366-383

Mueller B, Bos AR, Graf G, Gumanao GS. Size-specific locomotion rate and movement pattern of four common Indo-Pacific sea stars (Echinodermata; Asteroidea). Aquat Biol (submitted)

Nagelkerken I, Blaber SJM, Bouillon S, Green P, Haywood M, Kirton LG, Meynecke J-O, Pawlik J, Penrose HM, Sasekumar A, Somerfield PJ (2008) The habitat function of mangroves for terrestrial and marine fauna: a review. Aquat Bot 89:155-185

Oak T, Scheibling RE (2006) Tidal activity pattern and feeding behaviour of the ophiuroid Ophiocoma scolopendrina on a Kenyan reef flat. Coral Reefs 25:213-222

Pratchett MS, Schenk TJ, Baine M, Syms C, Baird AH (2009) Selective coral mortality associated with outbreaks of
Acanthaster planci L. in Bootless Bay, Papua New Guinea. Mar Environ Res 67:230-236

Ramsay K, Turner JR, Vize SJ, Richardson CA (2000) A link between predator density and arm loss in the starfish Marthasterias glacialis and Asterias rubens. J Mar Biol Assoc UK 80:565-566

Rosenberg R, Nilsson HC, Hollertz K, Hellman B (1997) Densitydependent migration in an Amphiura filiformis (Amphiuridae, Echinodermata) infaunal population. Mar Ecol Prog Ser 159:121-131

Run JQ, Chen CP, Chang KH, Chia FS (1988) Mating behaviour and reproductive cycle of Archaster typicus (Echinodermata: Asteroidea). Mar Biol 99:247-253

Scheibling RE, Metaxas A (2008) Abundance, spatial distribution, and size structure of the sea star Protoreaster nodosus in Palau, with notes on feeding and reproduction. Bull Mar Sci 82:211-235

Scheibling RE, Metaxas A (2010) Mangroves and fringing reefs as nursery habitats for the endangered Caribbean sea star Oreaster reticulatus. Bull Mar Sci 86:135-150

Schoppe S (2000) Echinoderms of the Philippines. Times Edition, Singapore

Shibuno T, Nakamura Y, Horinouchi M et al (2008) Habitat use patterns of fishes across the mangrove-seagrass-coral reef seascape at Ishigaki Island, southern Japan. Ichthyol Res 55:218-237 